ADALAH : Buletin Hukum \&

Keadilan

Buletin Hukum \& Keadilan

@adalahuinjkt

buletin.adalah

\title{
Penerapan Judicial Restraint Dalam Pengujian Undang- Undang Terhadap Undang-Undang Dasar 1945
}

Siti Nurhalimah*

Sebagai cabang kekuasaan kehakiman yang memiliki wewenang untuk menguji undangundang terhadap Undang-Undang Dasar 1945, Mahkamah Konstitusi dinilai sering kali mengeluarkan putusan yang bersifat kontroversial. Sehingga, muncullah berbagai gagasan para pakar hukum untuk membatasi kekuasaan kehakiman, yang salah satunya ialah untuk menerapkan Judicial Restraint.

Menurut Posner dalam dalam jurnal Wicaksana Dramanda dikatakan bahwa:

"Judicial restraint merupakan upaya hakim atau pengadilan untuk membatasi diri dalam kerangka prinsip pemisahan kekuasaan (separation of powers). Hal ini berarti bahwa judicial restraint adalah upaya dari cabang kekuasaan kehakiman untuk tidak mengadili perkaraperkara yang akan dapat mengganggu cabang kekuasaan yang lain. Posner beranggapan bahwa pengadilan bukanlah "primary custodian" dalam sistem politik sebuah negara yang dapat menentukan kesejahteraan sosial. Oleh karena itu, pengadilan hanya diperkenankan untuk mengadili perkara-perkara yang ditentukan secara limitatif berdasarkan hukum sebagai ewenangannya" (Dramanda, 2014: 620).

Dari pendapat Posner tersebut, dapat dipahami bahwa konsep Judicial Restraint bertujuan untuk menjaga dan mempertahankan hakikat Mahkamah Konstitusi

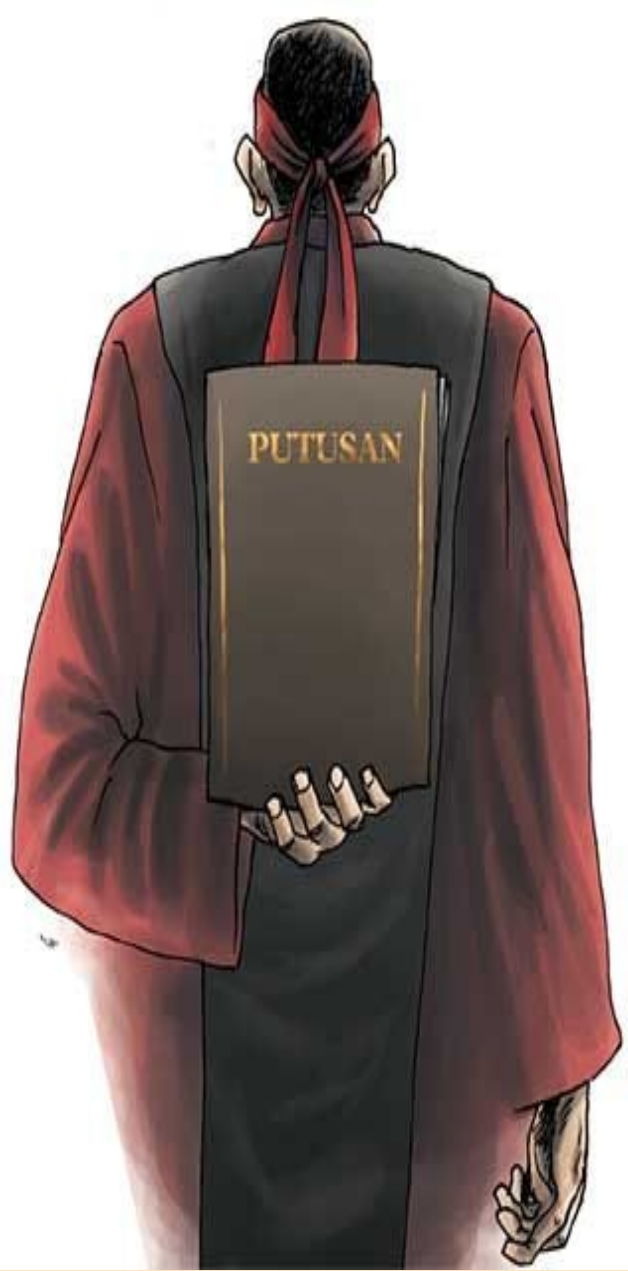

sebagai negatif legislator, dan berjalan sesuai kewenangannya sebagaimana yang telah digariskan dalam Undang-Undang Dasar 1945.

Gagasan untuk menerapkan Judicial Restraint tersebut muncul karena dalam praktiknya, Mahkamah Konstitusi tidak hanya melakukan pengujian undangundang terhadap Undang-Undang
Dasar 1945, namun Mahkamah Konstitusi juga melakukan pengujian Peraturan Pemerintah Pengganti Undang-Undang (Perppu). Disamping itu, Mahkamah Konstitusi juga kerap bertindak layaknya miniparliament, dengan membuat norma baru terkait undang-undang yang sedang diuji nilai konstitusionalitasnya. Sehingga, penerapan Judicial 
Restraint di Mahkamah Konstitusi dinilai sebagai upaya yang tepat, demi menghindari putusan-putusan Mahkamah Konstitusi yang bersifat magnitudo, serta tindakan Mahkamah Konstitusi yang dinilai abuse, karena memutus dan menerima perkara bukan pada tupoksinya.

Jika ditelaah lebih dalam, sejatinya hal tersebut merupakan anggapan yang keliru. Karena pada dasarnya, Mahkamah Konstitusi selalu berjalan pada koridornya dengan tetap berhakikat negative legislator yang progresif, karena Mahkamah Konstitusi senantiasa memposisikan dirinya sebagai penerang norma hukum yang buram, sehingga norma hukum tersebut menjadi jelas, tajam, dan mengikat. Hal ini dilakukan Mahkamah Konstitusi demi menegakkan UndangUndang Dasar 1945 sebagai hukum tertinggi negara, serta memelihara konstitusional seluruh warga negara Indonesia.

Hal tersebut juga diamini oleh Dedy Nursamsi dengan mengutip pendapat Lord Bryce menyatakan bahwa, Undang-Undang Dasar 1945 memiliki satu fungsi dan tujuan utama, yaitu untuk menjamin perlindungan hukum atas hak seluruh anggota masyarakat Indonesia. Sehingga pasca

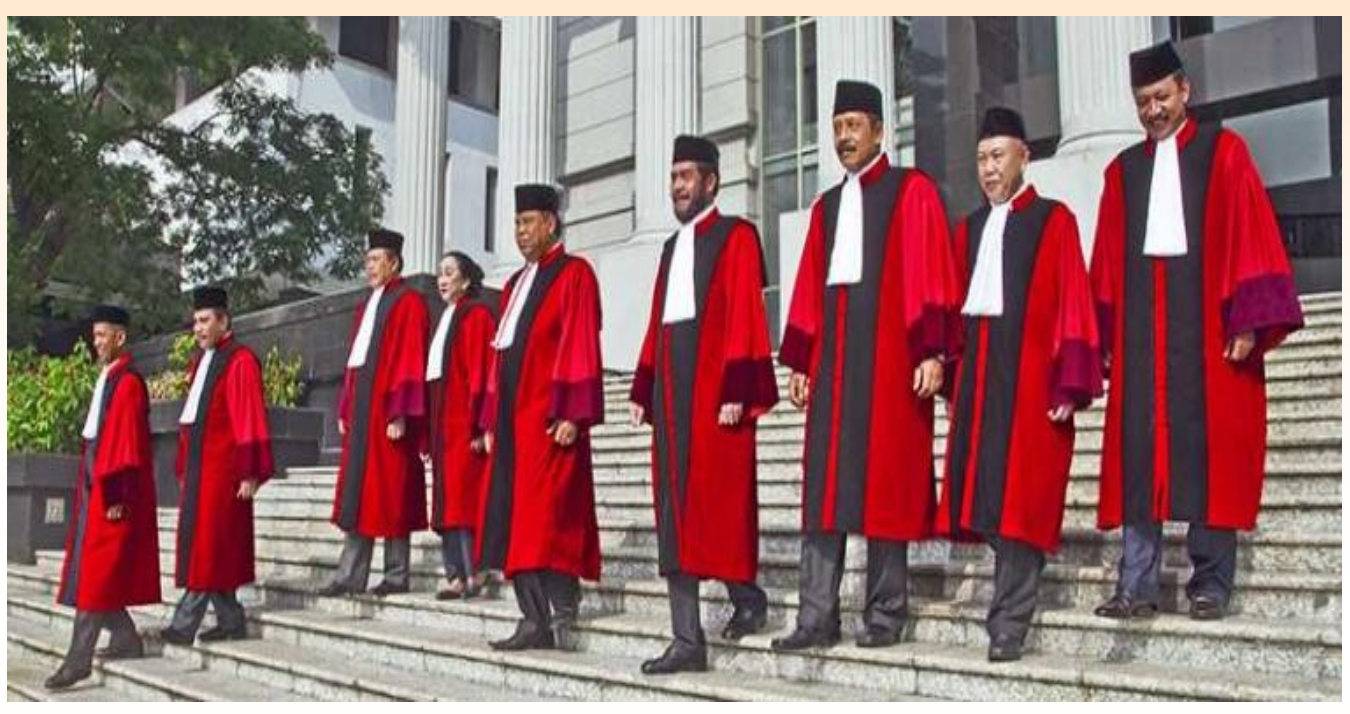
reformasi dalam amandemen ketiga Undang-Undang Dasar 1945, lahirlah maha karya akbar insan cita hukum Indonesia, yakni Mahkamah Konstitusi sebagai The Guardiant of Constitution and The protector of the citizen's constitutional rights.

Dalam perjalanannya mengawal konstitusi, Mahkamah Konstitusi senantiasa mengeluarkan putusan yang progresif. Seperti yang dilakukan mahkamah dewasa ini, yakni melakukan penafsiran norma hukum dengan konstitusional bersyarat maupun inkonstitusional bersyarat, serta terobosan Mahkamah Konstitusi lainnya dalam menegakkan keadilan berdasarkan konstitusi.

Seperti halnya putusan Mahkamah Konstitusi Nomor 10/PUU-VI/2008 mengenai calon DPD. Frasa yang ada dalam undang-undang hanyalah berdomisili di Indonesia, maka mahkamah memberikan putusan inkonstitusional bersyarat, selama tidak dimaknai bertempat tinggal di daerah konstituennya.

Begitu pun halnya putusan Mahkamah Konstitusi Nomor 100/PUU-XIII/2015 mengenai pilkada yang hanya dapat terselenggara jika terdapat dua paslon. Namun realita yang ada, terdapat lima daerah yang hanya memiliki satu paslon. Sehingga, Mahkamah Konstitusi menyatakan dalam putusannya, bahwa pilkada dapat tetap dilaksanakan meskipun hanya terdapat satu paslon.

Apabila Mahkamah terkekang dengan konsep Judicial Restraint sehingga tidak dapat melakukan penafsiran konstitusional dari berbagai dogma dan berbagai nilai-nilai di luar konstitusi, maka sejatinya Mahkamah Konstitusi hanya menjadi corong dari 